Original Research Article

\title{
Analgesic activity of Cissus quadrangularis linn with Zingiber officinale rosc in male wistar rats
}

\author{
Santosh Kumar ${ }^{1}$, Chakrapani Cheekavolu ${ }^{1 *}$, P. Leela ${ }^{2}$, Simhadri V. S. D. N. A. Nagesh ${ }^{3}$, \\ M. Naresh Kumar ${ }^{4}$, N. Jagan 5
}

${ }^{1}$ Department of Pharmacology, Kerala Medical College and hospital, Mangode, Palakkad, Kerala, India

${ }^{2}$ Department of Biochemistry, SVIMS, Tirupati, Andhra

Pradesh, India

${ }^{3}$ Department of Pharmacology,

Tagore Medical College \&

Hospital, Chennai, Tamil Nadu, India

${ }^{4}$ Department of Biochemistry, Sri Patanjali Maharshi Naturopathy\& Yoga Medical College, Guntakal, Andhra Pradesh, India

${ }^{5}$ Department of Pharmacology,

Texila American University,

Georgetown, Guyana, South

America

Received: 09 August 2017

Revised: 31 August 2017

Accepted: 01 September 2017

\section{*Correspondence to:}

Dr. Chakrapani Cheekavolu, Email: chakri14783@gmail.com

Copyright: () the author(s), publisher and licensee Medip Academy. This is an open-access article distributed under the terms of the Creative Commons Attribution Non-Commercial License, which permits unrestricted non-commercial use, distribution, and reproduction in any medium, provided the original work is properly cited.

\begin{abstract}
Background: The global scenario, human beings are using various forms of treatment for relief of pain; among them, medicinal plant products have gained popularity because of its wide range of use and less side effects.

Methods: Adult Albino rats of either sex were selected and divided into 5 groups. The Eddy's hot plate was used and maintained temperature $\left(55 \pm 0.5^{\circ} \mathrm{C}\right)$, the animals were placed on the hot plate and the time taken for paw licking or jumping was recorded and considered as nociceptive response. The reaction time was observed on $0,30,60$, and 90 minute.

Results: The hot plate reaction time in sec was collected in the intervals of 0, 30, 60 and 90 minutes in all groups. Reaction times as follows: group III (Cissus quadrangularis Linn.) were $2.18 \pm 0.04,3.13 \pm 0.05^{* *}, 5.83 \pm 0.05^{* *}, 5.39 \pm 0.04 * *$; Group IV (Zingiber officinale Rosc.) were $2.12 \pm 0.03,4.13 \pm 0.04 * *, 7.43 \pm 0.07 * *$, 7.16 $\pm 0.06^{* *}$; Group V Cissus quadrangularis Linn+ Zingiber officinale Rosc.) were $\quad 2.21 \pm 0.75, \quad 4.67 \pm 0.98^{* *}, \quad 8.15 \pm 0.89 * *, \quad 9.02 \pm 0.75^{* *}$; Group II (Dexamethasone) were $2.14 \pm 0.05,5.53 \pm 0.05 * *, 8.14 \pm 0.06 * *, 10.08 \pm 0.10^{* *}$ respectively, Results are presented as mean \pm SEM, $(\mathrm{n}=6),{ }^{*}<<0.01, * * \mathrm{p}<0.05$ dunnet test used as compared to control.

Conclusions: Present study reveals that, the combination treatment of Zingiber officinale Rosc. + Cissus quadrangularis Linn. has been shown significant analgesic effect. High analgesic effect was observed with combination therapy; the effect was shown same as standard drug dexamethasone.
\end{abstract}

Keywords: Analgesic, Cissus quadrangularis Linn, Hotplate, Zingiberofficinale Rosc

\section{INTRODUCTION}

Cissus quadrangularis Linn is family of vitaceae, commonly found in India especially hotter placeses of India. It can be cultivated in plains coastal areas, jungles and wastelands up to $500 \mathrm{~m}$ elevation various photochemical were, triterpenes including $\alpha$ - and $\beta$ amyrins, $\beta$-sitosterol, ketosteroids, phenols, tannins, carotene and vitamin $\mathrm{C}$ identified in methanol extract of Cissus quadrangularis Linn. ${ }^{1-3}$ The therapeutic effect depends upon their chemical constituents and Seven alicyclic lipids constituents also been reported from Cissus 
quadrangularis it's exhibits strong antioxidant and free radical scavenging activity in vitro and in vivo due to the presence of $\beta$-carotene oral administrations of Cissus quadrangularis extract does not produce any toxic effect (1mg/Kg daily for 10 days) in mice, rats. ${ }^{4-8}$ Cissus quadrangularis used as various conditions like antihelminthic, dyspeptic, digestive tonic, analgesic in eye and ear diseases, scurvy, irregular menstruation, asthma, fractures of bones. ${ }^{9,10}$ Zingiber officinale Rosc belongs to the family of Zingiberaceae available in South-East Asia and It has been cultivated used as flavour to Indian food. ${ }^{11}$ Besides also using in traditional herbal medicine and its having health-promoting perspective rich phytochemistry. ${ }^{12}$ The constituents of zingiber officinale rosc are various depending on the place of origin and form of rhizomes either fresh or dry, those contains several components i.e., carbohydrates, minerals, phytochemicals, proximate components like moisture, proteins, fats, fiber, and also contains appreciable amounts of vitamins and minerals as well as some enzymes. ${ }^{13}$

\section{METHODS}

\section{Selection of dose $e^{14}$}

The dose selection plays vital role in animal studies, as it may sometimes increase mortality rate of rats. So scientific and recognised procedures were followed. The dose for rats was calculated extrapolating the human therapeutic dose (HTD) using the following formula: Dose in rats/200 $\mathrm{g}$ of body weight $=\mathrm{HTD} \times 0.018(\mathrm{HTD}=5 \mathrm{gm} \mathrm{Bd})$ Here Rat dose $=$ Human dose $\times 0.018$ for $200 \mathrm{gm}$ rat weight. i. e. $5 \mathrm{gm} \times 0.018=0.09 \mathrm{gm}$ or $90 \mathrm{mg}$, Conversion to dose $/ \mathrm{Kg}$ body wt. $=90 \times 5=450 \mathrm{mg} / \mathrm{Kg}$

\section{Preparation of drug administration}

$10 \mathrm{gms}$ of each tested drug mixed in $100 \mathrm{ml}$ of water and kept overnight and next day morning it is filtered. From the filtrate $4.5 \mathrm{ml}$ of aqueous solution is given to each rat (4.5 ml=450mg).

\section{Animals}

Experimental Animals wister albino rats between 2 and 3 months of age (male) weighing 150-200 g were randomly selected and divided into the control and trial drug groups. The animals were kept in the cages for 5 days prior to the start of the study to allow acclimatized to the experimental room having ambient temperature $\left(23 \pm 2^{\circ} \mathrm{C}\right)$, controlled humidity $(55 \pm 5 \%)$ conditions, and 12 hours light and dark cycle. Animals were caged in polypropylene cages with maximum of three animals per cage. The rats were fed with standard food pellets and water ad libitum.

The experiment was carried out in Department of Pharmacology, V.P. Chest Institute, University of Delhi, New Delhi after obtaining the institutional animal ethical committee approval in accordance to the guidelines mentioned in the CPCSEA.

\section{Eddy's hot plate method $^{15}$}

Rats were divided into five groups of six each. The animals were placed individually in hot plate regulated at temperature $\left(55 \pm 0.5^{\circ} \mathrm{C}\right)$ before the treatment and its reaction time was determined. The tested drugs were given to each rat of different groups. Then the each animal was placed in the Eddy's hot plate under regulated temperature to obtain animal response licking of the forepaws or jump of the Hot plate surface was recorded as the hot-plate latency. The reaction time was noted by stop-watch and then the reaction time was re-determined after $0,30,60 \&$ $90 \mathrm{~min}$. after oral administration of standard and test drugs.

\section{Animal experimental groups}

- $\quad$ Group I: Normal saline (control) orally.

- Group II: Treatment of Dexamethasone in a dose of $8 \mathrm{ml} / \mathrm{kg}$ orally(Standard).

- Group III: Treatment of Cissus quadrangularis Linn.in a dose of $450 \mathrm{mg} / \mathrm{kg}$ orally.

- Group IV: Treatment of Zingiber officinale Rosc. in a dose $450 \mathrm{mg} / \mathrm{kg}$ orally.

- $\quad$ Group V: Treatment of both cissus quadrangularis Linn. with Zingiber officinale Rosc. in a dose of $450 \mathrm{mg} / \mathrm{kg}$ orally.

\section{Statistical analysis}

The statistical package Graph Pad Prism 3.1 version was used to analyse all results. Values are expressed as mean \pm SEM. One way ANOVA followed by post hoc Dunnett's test was used for analysis of data and for comparisons between treated and control groups; $p<0.05$ was considered significant.

\section{RESULTS}

Table 1: Analgesic activity by Eddy's Hot Plate method.

\begin{tabular}{|lllll|}
\hline \multirow{2}{*}{ Group } & \multicolumn{5}{l}{ Post drug reaction time(sec) } \\
\hline \multirow{2}{*}{ Oroup-I } & $2.11 \pm$ & $2.19 \pm$ & $2.19 \pm$ & $2.15 \pm$ \\
& 0.03 & 0.07 & 0.07 & 0.03 \\
\hline \multirow{2}{*}{ Group-II } & $2.14 \pm$ & $5.53 \pm$ & $8.14 \pm$ & $10.08 \pm$ \\
& 0.05 & $0.05^{* *}$ & $0.06^{* *}$ & $0.10^{* *}$ \\
\hline \multirow{2}{*}{ Group-III } & $2.18 \pm$ & $3.13 \pm$ & $5.83 \pm$ & $5.39 \pm$ \\
& 0.04 & $0.05^{* *}$ & $0.05^{* *}$ & $0.04^{* *}$ \\
\hline \multirow{2}{*}{ Group-IV } & $2.12 \pm$ & $4.13 \pm$ & $7.43 \pm$ & $7.16 \pm$ \\
& 0.03 & $0.04^{* *}$ & $0.07^{* *}$ & $0.06^{* *}$ \\
\hline \multirow{2}{*}{ Group-V } & $2.21 \pm$ & $4.67 \pm$ & $8.15 \pm$ & $9.02 \pm$ \\
& 0.75 & $0.98^{* *}$ & $0.89^{* *}$ & $0.75^{* *}$ \\
\hline
\end{tabular}

Results are presented as mean \pm SEM, $(n=6), * p<0.01$, $*_{*} \mathrm{p}<0.05$ dunnet test as compared to control. The control group at $0 \mathrm{~min}$. 30min, $60 \mathrm{~min}$ and $90 \mathrm{~min}$ shows hot plate reaction time in sec is $2.11 \pm 0.03,2.19 \pm 0.07,2.19 \pm 0.07$ and $2.15 \pm 0.03$ respectively. The corresponding mean 
volumes in Dexamethasone $(8 \mathrm{ml} / \mathrm{kg})$ treated group were $2.14 \pm 0.05, \quad 5.53 \pm 0.05 * *, \quad 8.14 \pm 0.06 * *, \quad 10.08 \pm 0.10 * *$ respectively, indicating significant analgesic activity of Dexamethasone from $60 \mathrm{~min}$ onwards when compared to control. Zingiber officinale Rosc. and combination extracts had produced significant increase in hot plate reaction time from 0 to $90 \mathrm{~min}$. The results of Zingiber officinale Rosc. and combination groups also showed significant analgesic effect, but the results of combination group were in par with standard drug group.

\section{DISCUSSION}

Zingiber officinale bioactive molecules are effective treatment of colorectal, gastric, ovarian, liver, skin cancers several studies support the fact that ginger can cure breast and prostate cancers. ${ }^{16-19}$ The anti-inflammatory effect of zingiber officinale has been scientific investigations reported concentration-dependent inhibition of arachidonic acid-induced platelet aggregation and formation of thromboxane B. Gingerol, shogaol, and other structurally-related substances in ginger inhibit prostaglandin and leukotriene biosynthesis through suppression of 5- lipoxygenase or prostaglandin synthetase and also inhibit synthesis of IL-1, TNF- $\alpha$ and IL-8 as proinflammatory cytokines. ${ }^{20,21}$ Antioxidant are rich in Zingiber officinale preparations and effective in reducing the extent of diabetes mellitus, pregnancy-induced maladies, arthritis, etc. This drug considered a safe herbal medicine with few adverse effects. Cissus quadrangularis exhibited significant inhibition in DPPH free radical formation, superoxide radical production and lipid peroxide production in erythrocytes. liver enzymes and oxidant defense enzymes controlled in experimental animals Cissus quadrangularis is an popular plant, commonly used in Ayurveda for treatment of gastric ulcers. $^{22}$ The anti-ulcer effect of a methanolic extract of Cissus quadrangularis was comparable to that of sucralfate. ${ }^{23}$ Cissus quadrangularis have an inhibitory effect on edema induced by both carrageenin and arachidonic acid, it is evident that both cyclooxygenase and lipoxygenase pathways of arachidonic acid metabolism are inhibited by Cissus quadrangularis. ${ }^{24}$ According to previous findings, the present study additionally demonstrated that, The Combination treatment of Zingiber officinale with Cissus quadrangularis have been high significant analgesic than the indusial preparation. More studies are needed to conduct kinetics of functional ingredients of tested drugs.

\section{CONCLUSION}

Present study reveals that, Zingiber officinale Rosc. and combination treatment of zingiber officinale Rosc.+ Cissusquadrangularis Linn was shown significant analgesic activity. The analgesic effect was nearly same as dexamethasone in the combination treatment of zingiber officinale + Cissusquadrangularis.
Funding: No funding sources

Conflict of interest: None declared

Ethical approval: The study was approved by the Institutional Ethics Committee

\section{REFERENCES}

1. Anonymous. Indian Medicinal Plants, Orient Longman Ltd.; Vol 2. 1992:112

2. Deka DK, Lahon LC, Saikia J, Mukit A. Effect of Cissus quadrangularis in accelerating healing process of experimentally fractured Radius Ulna of dog: A preliminary study. Indian Journal of Pharmacology 1994;26:44-8.

3. Demling RH. Oxandrolone, an anabolic steroid enhances the healing of a cutaneou wound in the rat. Wound Repair and Regeration. 2000;8:97-102.

4. Irfan AK, Atiya K. Herbal therapy for arthritis. Ukaaz publications; 2008:15-72.

5. Gupta MM, Verma RK. Lipid constituents of Cissus quadrangularis, Phytochemistry. 1991;30:875-8.

6. Murthy KNC, Vanitha A, Swami MM, Ravi SG. Antioxidant and antimicrobial activity of Cissus quadrangularis L. Journal of Medical Food. 2003;6:99-105.

7. Mallika J, Shyamala Devi CS. In vitro and In vivo evaluation of free radical scavenging potential of Cissus quadrangularis. African Journal of Biomedical Research 2005; 8: 95-99.

8. Research Guidelines for evaluating the safety and efficacy of herbal medicines. WHO Regional Office, Western Pacific. Manila; 1994.

9. Nadkarni AK. In: Indian Materia Medica. 3rd ed. Mumbai: Popular Book Depot; 1954:1284.

10. Kirtikar KR, Basu BD. Cissus quadrangularis Indian medicinal plants. Blatter E, Calus JE, Mhasker KS, editors. Allahabad; 1933:604.

11. Park EJ, Pizzuto JM. Botanicals in cancer chemoprevention. Cancer Metast. Rev. 2002;21:23155.

12. Shukla Y, Singh M. Cancer preventive properties of ginger: a brief review. Food Chem. Toxicol. 2007;45:683-90.

13. Rao R, Platel K, Srinivasan K. In vitro influence of spices and spice-active principles on digestive enzymes of rat pancreas and small intestine. Nahrung. 2003;47:408-12.

14. Ghosh MN. Fundamentals of experimental pharmacology $2^{\text {nd }}$ Edition, scientific book Agency, Calcutta; 1984:155.

15. Eddy NB, Leimbach D. Synthetic analgesics 11, diethyl-butenye and diethienyl butyl amines. J Pharmacol Exp Ther. 1953;107:385-93.

16. Ishiguro K, Ando T, Watanabe O, Goto H. Specific reaction of alpha,beta-unsaturated carbonyl compounds such as [6]- shogaol with sulfhydryl groups in tubulin leading to microtubule damage. FEBS Lett. 2008;582:3531-6.

17. Sung B, Jhurani S, Ahn KS, Mastuo Y, Yi T, Guha S, et al. Zerumbone down-regulates chemokine receptor 
CXCR4 expression leading to inhibition of CXCL12induced invasion of breast and pancreatic tumor cells. Cancer Res. 2008;68:8938-44.

18. Lee HS, Seo EY, Kang NE, Kim WK. [6]-Gingerol inhibits metastasis of MDA-MB-231 human breast cancer cells. J. Nutr. Biochem. 2008;19:313-19.

19. Sung B, Murakami A, Oyajobi BO, Aggarwal BB. Zerumbone abolishes RANKL-induced NF-kappaB activation, inhibits osteoclastogenesis, and suppresses human breast cancer-induced bone loss in athymic nude mice. Cancer Res. 2009;69:1477-84.

20. Guh JH, Ko FN, Jong TT, Teng CM. Antiplatelet effect of gingerol isolated from Zingiber officinale. J. Pharm. Pharmacol. 1995;47:329-32.

21. Tjendraputra E, Tran VH, Liu-Brennan D, Roufogalis BD, Duke CC. Effect of ginger constituents and synthetic analogues on cyclooxygenase-2 enzyme in intact cells. Bioorganic Chem. 2001;29:156-63.
22. Brown RK, Kelly FG. Evidence for increased oxidative damage in patients with cystic fibrosis, Paediatric Res. 1994;36:487-93.

23. Szabo S, Trier JS, Brown A, Schoor J. Early vascular injury and increased permeability in gastric mucosal injury caused by ethanol in rat. Gastroenterology. 1985;88:228-36.

24. Dela PR, Martinez-Dominguez E, Ruiz GV. Effect of minor components of virgin olive oil on topical antiinflammatory assays, Zetschrift Fur Naturforschong. 2000;55:814-9.

Cite this article as: Kumar S, Chakrapani C, Leela P, Simhadri VSDNAN, Kumar MN, Jagan N. Analgesic activity of Cissus quadrangularis linn with Zingiber officinale rosc in male wistar rats. Int J Basic Clin Pharmacol 2017;6:2496-9. 